\title{
A SEVENTEEN KILODALTONS PEPTIDYL-PROLYL CIS-TRANS ISOMERASE OF THE CYCLOSPORIN-PRODUCER Tolypocladium inflatum IS SENSITIVE TO CYCLOSPORIN A
}

\author{
Rainer Zocher, Ullrich Keller, Chan Lee and Kar Hoffmann \\ Institut für Biochemie der Technischen Universität Berlin, \\ Franklinstrasse 29, D-1000 Berlin 10, Germany
}

(Received for publication July 18, 1991)

\begin{abstract}
A peptidyl-prolyl cis-trans isomerase (PPIase) was purified to homogeneity about 24-fold from the cyclosporin-producing fungus Tolypocladium inflatum. The molecular mass of the enzyme was in the range of $17 \mathrm{kdaltons}$. Remarkably, the enzyme could be inhibited by cyclosporin $\mathrm{A}$ in the nanomolar range as has been shown for numerous other cyclophilins from eukaryotic organisms. This indicates, that Tolypocladium inflatum must possess a self protection system in order to survive in the presence of cyclosporin.
\end{abstract}

Cyclosporins are produced by the fungus Tolypocladium inflatum ${ }^{1)}$. We have demonstrated that these cyclopeptides are synthesized by a large multifunctional enzyme in a non-ribosomal mechanism ${ }^{2 \sim 5\}}$. Cyclosporins possess both immunosuppressive and antifungal activities and it is believed that their action is mediated by highly specific cyclosporin-binding proteins, the cyclophilins ${ }^{6 \sim 8)}$. It has been shown recently, that cyclophilins are identical with peptidyl-prolyl cis-trans isomerases (PPIases), a class of enzymes catalysing the isomerization of peptide-proline bonds ${ }^{9,10)}$. These activities are believed to be involved in the correct folding of proteins in the cell ${ }^{11}$. Cyclophilins have been isolated from a variety of organisms ${ }^{12)}$ and obviously they play a fundamental biochemical role in all organisms.

In addition, the recent discovery of another binding protein for the immunosuppressive agent, FK $506^{13)}$, and its identification as a peptidyl-prolyl cis-trans isomerase ${ }^{14,15)}$ strongly suggests the involvement of peptide isomerization in events leading to the immune response. Likewise in the case of cyclophilins, it could be shown that in lower eukaryotes the cytotoxic activity of rapamycin, a compound structurally related to FK-506, is mediated by the FK-506 binding protein (FKBP) ${ }^{16)}$. FKBP and cyclophilin, however, differ from each other by their $\mathrm{M}_{\mathrm{r}} \mathrm{s}$, amino acid sequences and in that either of them cannot be inhibited by the inhibitor of the other one.

In view of the fact that the fungus $T$. inflatum produces cyclosporin, we were interested to see whether this organism contains a cyclophilin that can be inhibited by cyclosporin or not. If yes, this would imply that it must possess a self protection system against its own secondary metabolite. The present paper describes the purification and partial characterization of such an enzyme from that organism.

\section{Materials and Methods}

Media and Growth of Organism

Strain Tolypocladium inflatum DSM 915 was maintained on agar slants as described previously ${ }^{5}$. For submerged culture in this study the following liquid media were used: MCP-medium contained maltose $(6 \%, \mathrm{w} / \mathrm{v})$, casein peptone $(2 \%)$, potassium phosphate $(7.3 \mathrm{mM}), \mathrm{KCl}(33 \mathrm{mM}), \mathrm{pH}$ 5.5. CM-medium consisted of $10 \%$ cornsteep liquor and $30 \%$ sugar beet molasses and HMM-medium contained $0.5 \%$ malt extract, $0.5 \%$ yeast extract, $0.5 \%$ maltose, $\mathrm{pH} 7.5$ adjusted with $\mathrm{NaOH}$. All media were autoclaved at $121^{\circ} \mathrm{C}$ for 
20 minutes. Generally, $100 \mathrm{ml}$ portions of liquid medium in $500-\mathrm{ml}$ Erlenmeyer flasks were inoculated with $100 \mu \mathrm{l}$ aliquots of spore suspensions made from agar slants $\left(5 \sim 8 \times 10^{8}\right.$ spores $\left./ \mathrm{ml}\right)$ and agitated in an New Brunswick Controlled Environmental Shaker (model G25) at $110 \mathrm{rpm}$ and $26^{\circ} \mathrm{C}$. After 48 hours of growth, mycelium was harvested by suction filtration, washed with distilled water and freeze-dried.

\section{Enzyme Purification}

All operations were carried out at $2 \sim 4^{\circ} \mathrm{C} .10 \sim 12 \mathrm{~g}$ of lyophilized mycelium grown in HMM-medium were homogenized in a mortar and subsequently stirred in $200 \mathrm{ml}$ of buffer $\mathrm{A}(0.1 \mathrm{M}$ Tris $-\mathrm{HCl}, \mathrm{pH} 8,2 \mathrm{mM}$ dithioerythritol). After centrifugation of the suspension at $14,000 \mathrm{rpm}$ in the SS 34 rotor of a Sorvall RC-2B centrifuge for 20 minutes, the pellet was discarded and to the supernatant (crude extract) was added a $1 \%$ polyethylene solution (in water) to give a final concentration of $0.2 \%$. The resultant suspension was left on ice for 20 minutes. Then the precipitate was removed by centrifugation as above. To the supernatant was added saturated ammonium sulfate solution to give a final concentration of $80 \%$. After 1 hour of standing on ice, the precipitate was collected by centrifugation $(10,000 \mathrm{rpm}, 30$ minutes, GSA rotor, $\mathrm{RC}-2 \mathrm{~B}$ centrifuge) and the resultant protein pellet extracted with $25 \mathrm{ml}$ of buffer $\mathrm{A}$. Undissolved protein was removed by centrifugation and the supernatant applied onto an Ultrogel AcA 54 column $(55 \mathrm{~cm} \times 3.5 \mathrm{~cm})$ previously equilibrated with buffer A. Fractions of $10 \mathrm{ml}$ were collected and tested for PPIase activity. Fractions containing enzyme were pooled and passed through a Mono QHR 10/10 column previously equilibrated with buffer $\mathrm{A}$. The flow-through was brought to $80 \%$ saturation with solid ammonium sulfate and kept on ice overnight. Protein was collected by centrifugation as above, dissolved in $2 \mathrm{ml}$ of buffer $\mathrm{A}$ and subjected to fast performance liquid chromatography on a Superdex 75 $16 / 60$ column (Pharmacia) which had been previously equilibrated with $50 \mathrm{~mm}$ potassium phosphate, $\mathrm{pH}$ $6.8,2 \mathrm{~mm}$ dithioerythritol (buffer $\mathrm{C}$ ). The flow rate was $0.5 \mathrm{ml} /$ minute.

\section{Enzyme Assay}

PPIase activity was measured essentially as described ${ }^{9}$. The peptide Succ-Ala-Ala-Pro-Phe-pNA (Bachem) was used as the test substrate. In some rare cases the presence of cyclophilin in protein fractions was determined by an Sephadex LH-20 bindings assay using radioactively labeled cyclosporin ${ }^{6}$.) Radioactive cyclosporin A was prepared enzymatically as described ${ }^{3)}$.

Methods of Analyses

Protein determinations were done as described ${ }^{17}$. Slab gel electrophoresis was done according to LAEMMLI's method in a Hoefer Scientific minigel apparatus ${ }^{18)}$.

\section{Results and Discussion}

When the fungus T. inflatum was grown in MCP- or CM-medium, in which the organism produces cyclosporin, no cyclosporin-sensitive PPIase activity could be detected in crude and partially purified protein extracts from the cells. In view of the fact that cyclophilin is a ubiquitous protein, we argued that the failure to detect it might be due to the presence of cyclosporin in these preparations. In fact, we observed that the harvested cells still contained (despite extensive washing) cyclosporin in varying amounts (depending on the age of culture) (results not shown). However, it was not possible to distinguish between the two possibilities, i.e. whether the cyclosporin was inside the cells or adhering to the cell wall. As a matter of fact, cyclophilin would come into contact with cyclosporin during cell rupture in either of the two cases and this would lead to an inactivation of PPIase activity. In order to prove the existence of a cyclophilin in $T$. inflatum we sought a growth medium in which cyclosporin production would not take place. Experimentation led to the use of HMM-medium in which the fungus grows vigorously but does not produce cyclosporin in the first three days of cultivation (results not shown). Only in the stationary phase does the fungus produce minute amounts (less than $1 \mathrm{mg} /$ liter) of cyclosporin. Mycelium from the 
Table 1. Purification of $17 \mathrm{kdaltons}$ PPIase (cyclophilin) from Tolypocladium inflatum ${ }^{\mathrm{a}}$.

\begin{tabular}{llccrrr}
\hline \multicolumn{1}{c}{ Step } & $\begin{array}{c}\text { Volume } \\
(\mathrm{ml})\end{array}$ & $\begin{array}{c}\text { Protein } \\
(\mathrm{mg})\end{array}$ & $\begin{array}{c}\text { Units } \\
(\text { arb.) }\end{array}$ & $\begin{array}{c}\text { Spec. Activity } \\
\text { (units/mg) }\end{array}$ & $\begin{array}{c}\text { Recovery } \\
(\%)\end{array}$ \\
\hline 1. Crude extract & 25 & 63 & 32,000 & 508 & 100 \\
2. Polyethylenimine precipitate & 30 & 52 & 30,000 & 576 & 94 \\
3. (NH $)_{2} \mathrm{SO}_{4}$-precipitate & 25 & 27 & 27,500 & 1,018 & 86 \\
4. Ultrogel AcA 54 gel filtration & 90 & 4.5 & 11,500 & 2,555 & 36 \\
5. Passage through Mono Q & 90 & 2.5 & 9,000 & 3,600 & 28 \\
6. Gel filtration on Superdex 75 & 6 & 0.45 & 5,500 & 12,222 & 17 \\
\hline
\end{tabular}

a $12 \mathrm{~g}$ of lyophilized mycelium were used.

Fig. 1. Purification of cyclophilin (17 kdaltons PPIase) from Tolypocladium inflatum.

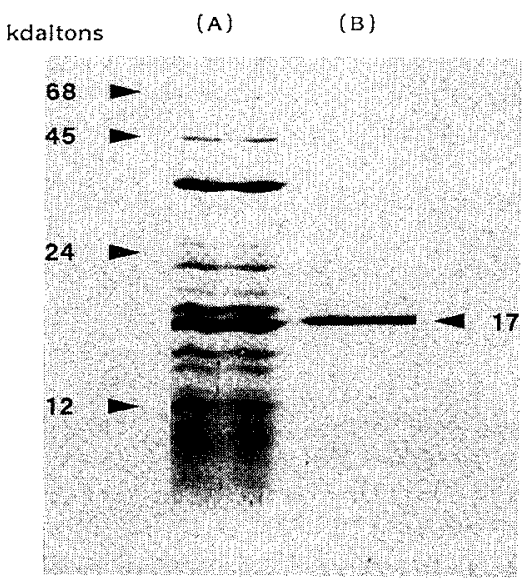

Protein samples from step 5 (Mono Q) (lane A) and step 6 (Superdex 75 gel filtration) (lane B) were separated in a $15 \%$ SDS polyacrylamide gel. Staining was with Coomassie Blue. $\mathrm{M}_{\mathrm{r}} \mathrm{s}$ of standard proteins are given on the left.
Fig. 2. Inhibition of 17 kdaltons PPIase activity by cyclosporin.

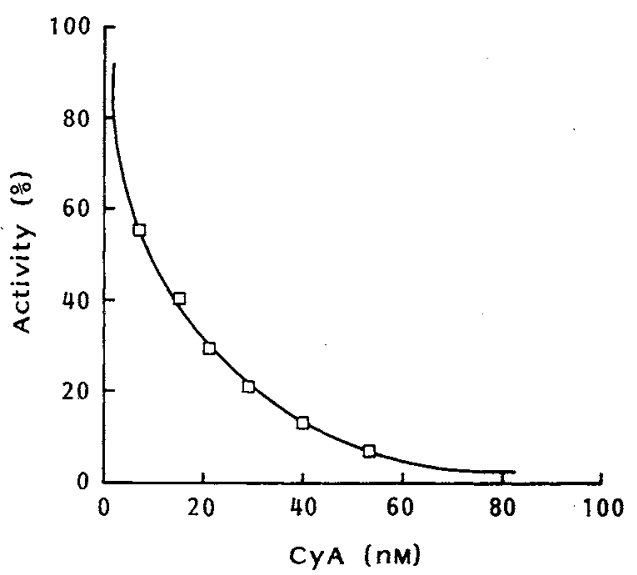

$5 \mu \mathrm{g}$ of purified enzyme was incubated under assay conditions with varying concentrations of cyclosporin $A$ as indicated.

growth phase in these conditions enabled us to detect PPIase activity in Tolypocladium cell extracts and also to purify it (Table 1). The overall purification was 24 -fold and the recovery was $17 \%$. Gel electrophoretic analysis revealed one single band in the last step of purification (Fig. 1) and indicated an $\mathrm{M}_{\mathrm{r}}$ of 17,000 . The enzyme was highly sensitive to cyclosporin in the nanomolar range (Fig. 2) as was to be expected when one considers other cyclophilins from lower and higher eukaryotes in their size and inhibition constants. Besides PPIase activity related to cyclophilin, all enzyme fractions from Table 1 except the last step also contained PPIase activity that was not inhibited by cyclosporin but by FK-506. This latter activity was also detected in cells grown in media allowing the production of cyclosporin. These findings are a further confirmation that in cyclosporin-producing cells, cyclophilin is present as is FKBP and that the failure to detect cyclophilin is caused by the presence of cyclosporin during cell disintegration. This leads to the irreversible inactivation of cyclophilin.

The results presented here suggest a strong compartmentalization of cyclosporin and/or its synthesis in cells of $T$. inflatum in order to prevent it from contact with cyclophilin which is usually cytosolic ${ }^{12)}$. Although the mechanism of self protection is not known, it is conceivable that cyclosporin may be excreted directly into the medium or stored in a cell organelle such as the vacuole. 
Acknowledgments

This work was supported by the Deutsche Forschungsgemeinschaft (Sfb 9, C 3).

\section{References}

1) Dreyfuss, M.; E. Härri, H. Hofmann, H. H. Kobel., W. Pache \& H. Tscherter: Cyclosporin A and C, new metabolites from Trichoderma polysporum. Eur. J. Appl. Microbiol. 3: 125 133, 1976

2) Zocher, R.; N. Madry, H. Peeters \& H. Kleinkauf: Biosynthesis of cyclosporin A. Phytochemistry 23: 549 551, 1984

3) Zocher, R.; T. Nihira, E. Paul, N. Madry, H. Peeters, H. Kleinkauf \& U. Keller: Biosynthesis of cyclosporin A: Partial purification and properties of a multifunctional enzyme from Tolypocladium inflatum. Biochemistry 25 : $550 \sim 553,1985$

4) Billich, A. \& R. Zocher: Enzymatic synthesis of cyclosporin A. J. Biol. Chem. 262: 17258 17259, 1987

5) LAWEN, A. \& R. Zocher: Cyclosporin synthetase, the most complex peptide synthesizing multienzyme so far described. J. Biol. Chem. 265: 11355 11360, 1990

6) Handschumacher, R. E.; M. W. Harding, J. Rice, R. J. Drugge \& D. W. Speicher: Cyclophilin: A specific cytosolic binding protein for cyclosporin A. Science 226: 544 547, 1984

7) HaRding, M. W. \& R. E. HANDSChumaChER: Cyclophilin, a primary molecular target for cyclosporine. Transplantation 46: 29S 35S, 1988

8) Tropschug, M.; I. B. Barthelmess \& W. Neupert: Sensitivity to cyclosporin A is mediated by cyclophilin in Neurospora crassa and Saccharomyces cerevisiae. Nature 342: 953 955, 1989

9) Fischer, G.; B. Wittmann-Liebold, K. Lang, T. Kiffhaber \& F. X. Schmid: Cyclophilin and peptidyl-prolyl cis-trans isomerase are probably identical proteins. Nature 337: 476 478, 1989

10) Takahashi, N.; T. Hayano \& M. Suzuki: Peptidyl-prolyl cis-trans isomerase is the cyclosporin A-binding protein cyclophilin. Nature 337: 473 475, 1989

11) FiSCHER, G. \& F. X. SCHMID: The mechanism of protein folding. Implications of in vitro refolding models for de novo protein folding and translocation in the cell. Biochemistry 29: 2205 2212, 1990

12) Koletzky, A. J.; R. E. Handschumacher \& M. W. Harding: Cyclophilin: distribution and variant properties in normal and neoplastic tissues. J. Immunol. 137: 1054 1059, 1986

13) Siekierka, J. J.; M. J. Staruch, S. H. Y. Hung \& N. H. Sigal: FK-506, a potent novel immunosuppressive agent, binds to a cytosolic protein which is distinct from the cyclosporin A-binding protein, cyclophilin. J. Immunol. 143: $1580 \sim 1583,1989$

14) Siekierka, J. J.; S. H. J. Hung, M. Poe, C. S. Lin \& N. H. Sigal: A cytosolic binding protein for the immunosuppressant FK 506 has peptidyl-prolyl isomerase activity but is distinct from cyclophilin. Nature 341 : $755 \sim 757,1989$

15) Harding, M. W.; A. Galat, D. E. Uehling \& S. L. Schreiber: A receptor for the immunosuppressant FK 506 is a cis-trans peptidyl-prolyl isomerase. Nature 341: 758 760, 1989

16) Koltin, Y.; L. Faucette, D. J. Bergsma, M. A. Levy, R. Cafferkey, P. L. Koser, R. K. Johnson \& G. P. Livi: Rapamycin sensitivity in Saccharomyces cerevisiae is mediated by a peptidyl-prolyl cis-trans isomerase related to human FK 506-binding protein. Mol. Cell. Biol. 11: 1718 1723, 1991

17) BRADFORD, M.: A rapid and sensitive method for the quantitation of microgram quantities of protein utilizing the principle of protein-dye binding. Anal. Biochem. 72: $248 \sim 254,1976$

18) LAFMMLI, U. K.: Cleavage of structural proteins during the assembly of the head of bacteriophage T4. Nature 227: $680 \sim 685,1970$ 